\title{
CEO Overconfidence and Voluntary Disclosure of Greenhouse Gas Emissions: With a Focus on the Role of Corporate Governance
}

\author{
Jaehong Lee (D)
}

Citation: Lee, J. CEO Overconfidence and Voluntary Disclosure of Greenhouse Gas Emissions: With a Focus on the Role of Corporate Governance. Sustainability 2021, 13, 6054. https://doi.org/10.3390/ su13116054

Academic Editor: Diego Luis Valera Martínez

Received: 7 April 2021

Accepted: 8 May 2021

Published: 27 May 2021

Publisher's Note: MDPI stays neutral with regard to jurisdictional claims in published maps and institutional affiliations.

Copyright: (C) 2021 by the author. Licensee MDPI, Basel, Switzerland. This article is an open access article distributed under the terms and conditions of the Creative Commons Attribution (CC BY) license (https:/ / creativecommons.org/licenses/by/ $4.0 /)$.
Major in Accounting/Taxation, College of Software and Management, Kyonggi University, Suwon 16227, Korea; jhong@kgu.ac.kr

\begin{abstract}
The purpose of this study is to investigate the relationship between overconfident CEOs, voluntary disclosure of greenhouse gas emissions and firm value, and whether corporate (internal and external) governance affects this association. Using logistic regression and a firm-fixed effect model, I analyzed a sample of voluntary disclosing firms with the fiscal year in December that are listed in the Korean stock market for the period from 2011 to 2019, measuring corporate governance based on female representation within boards and industry-level competition. As a result, this study finds that, on average, CEO overconfidence is positively related to voluntary disclosure of greenhouse gas emissions. Moreover, in firms with more female representation on boards, the positive relationship between CEO overconfidence, voluntary disclosure of greenhouse gas emissions, and firm value is more pronounced, implying that women directors effectively monitor overconfident CEOs. Similarly, this positive relationship is also strengthened according to the degree of industry-level competition, which indicates that the external governance role of competition can alleviate CEO overconfidence. This study is meaningful as the first study to examine the effect of voluntary greenhouse gas (GHG) emissions disclosure on investors' valuation in the Korean capital market, taking the characteristics of managers and governance structure into account.
\end{abstract}

Keywords: CEO overconfidence; voluntary disclosure of greenhouse gas emissions; woman executives; industry-level competition; firm value

\section{Introduction}

Since the Industrial Revolution, rapid social changes have resulted in the material abundance necessary for human life, but the counterattack of nature has begun to be recognized as a major crisis to humanity through climate change. In particular, due to resource depletion and the destruction of the global environment, such as soil pollution, ozone layer destruction, and global warming, humanity has come to feel the need for accountability from the industrial society and raise concerns about the sustainable existence of the earth. To solve these problems, in the 21st century, the global capital market was reorganized into trade liberalization and a green round economy related to the environment under the WTO system. Companies become aware of the necessity of carrying out eco-friendly management activities to effectively respond to these environmental challenges and gain an edge in market competition. In addition, investors have begun to actively demand that companies create continuous profits by securing a competitive advantage through environmental management, supporting the notion that the corporate environmental management acts as an essential factor in corporate valuation.

As public interest in climate change in South Korea has increased in recent years, a need for companies to disclose environmental issues and greenhouse gas (GHG) emissions has emerged. In 1996, in the process of revising corporate accounting standards by the Korea Securities Management Commission, the Korean government stipulated that 
environmental information could be included in footnotes on financial statements. Subsequently, in 1998, the Financial Supervisory Commission enacted to include information on corporate environmental policies and standards, safety and accident matters, environmental investment, the consumption of resources and energy, and generation and disposal of waste in financial statements. However, since environmental accounting information is additionally disclosed in the notes on financial statements in a supplementary manner, it does not clearly state what content should be included in each required item. In addition, there are differences in the level of objectivity since opinions differ from company to company regarding the importance of items and the quality of disclosure of environmental accounting information, which most companies overlook because the disclosure of environmental accounting information is not mandatory. However, there has been an improvement in the public awareness of the emergence of private environmental organizations, the green consumers' purchasing power, the impact of investments in eco-friendly companies, and the general quality of life, all of which increase the need and demand for environmental management, which, in turn, leads to a gradual increase in the number of companies that disclose environmental information.

The great interest in the voluntary disclosure of environmental information was also sufficient to attract the attention of academia. Recent studies documented that corporate proactive environmental activities and disclosures are related to reputational assets, stockholders' attractiveness, and investors' satisfaction, which lead to positive economic consequences. Prior studies suggest that environmental disclosures are associated with positive firm value. Matsumura et al. (2014) report that investors view carbon emission disclosures as value-relevant for firm value [1]. Similarly, stockholders react positively to the environmental disclosure, and that the reactions are more favorable for smaller firms with restricted public information accessibility and firms within environmentally sensitive industries [2,3]. Botosan and Plumlee (2002) report that firms with a high degree of disclosure level can enjoy lower costs for equity financing [4]. Dhaliwal et al. (2011) show that firms that voluntarily disclose their environmental information induce lower costs of equity capital [5]. In a similar vein, timely sustainability reports in the capital market create a positive market reaction [6]. Since lower costs for equity are associated with higher market value, it is plausible that voluntary environmental disclosure such as greenhouse gas (GHG) emission can increase the market value of equity. Finally, voluntary disclosure can be strategically used to mitigate the negative externalities when firms lack environmental reputation [7]. Even when chemical companies perceive negative stock price returns after a significant chemical leak, the share price quickly recovers for firms with better environmental disclosure, and chemical firms with a high degree of environmental disclosure show a weak negative response to environmental regulations, compared with other firms [8,9]. Corporate reputation capital is developed through social environmental responsibility, product quality, ownership structure, media visibility, financial performance, and board composition. Voluntary environmental disclosures (even without behavior changes) can be regarded as an act of paying attention to the firm's environmental concerns, signaling the will to make a positive impact on society. Overall, prior studies focus on the fact that voluntary environmental disclosures compile intangible assets such as reputation capital $[10,11]$, which leads to an increase in investors' wealth in the long term [12].

Healy and Palepu (2001) suggest that various factors may affect managerial voluntary disclosure behavior [13]. Among the various factors, such as capital market reactions, stock-based compensation, litigation risk, proprietary costs, and managerial personal characteristics, this paper focuses on the CEO feature of overconfidence. Overconfident CEOs are described based on the psychological aspects of individual characteristics. In particular, CEO overconfidence refers to the tendency of managers to trust excessively in their abilities or performance, and if this tendency is excessive, companies may be biased toward errors or prejudices in the decision-making process [14]. From the perspective of upper echelon theory, managers' personal values, dispositions, and past experiences profoundly influence the CEO's decision-making, and they are more likely to adopt a corporate strategy that fits 
their individual preferences rather than maximizing the interests of shareholders [15]. Considering that managers are a core factor influencing corporate economic decision-making, it seems natural that voluntary disclosure of environmental issues is affected by the management preference system and individual psychological characteristics [16]. The decision to disclose information on greenhouse gas (GHG) emissions of great social interest provides a significant opportunity to show the ability of overconfident CEOs who have higher demands for attention and praise and a strong desire to strengthen a positive self-image. The reason that greenhouse gas (GHG) emissions are directly measured and disclosed is that the company manager possesses environmental knowledge and values and, through such disclosure, they can show the market their willingness to practice environmental action. The fact that managers directly measure and voluntarily disclose greenhouse gas (GHG) emissions is an opportunity to indirectly prove that managers will practice an environment-friendly strategy based on professional environmental knowledge and values. Besides, voluntary disclosure of environmental issues is sensitive to market participants in terms of respect, media attention, and praise, all of which are external causes to convey attention [17]. Lastly, companies that voluntarily disclose greenhouse gas (GHG) emissions can derive various benefits from changing the present image, bringing opportunities for stability and diversity to overconfident management who have to expose themselves to attentive and responsive shareholders.

Although prior research generally provides negative results about overconfident CEOs through managing financial statements and unethical behaviors and fraud [18-20], relatively little attention has been paid to its positive influence on strategic disclosing decision and firm value; namely, $\mathrm{CEO}$ overconfidence can instead boost effective leadership and guidance [21]. Thus, this paper attempts to investigate whether CEO overconfidence affects voluntary disclosure decisions on greenhouse gas (GHG) emissions. As Jensen and Meckling's agency theory postulates that overconfident CEOs have the motivation to maximize their private benefits through environmental disclosure, they will over-commit to engagement in voluntary disclosure on greenhouse gas (GHG) emissions and, as such, those environmental disclosures enhance their reputational capital as ecological citizens and generate a warm-glow effect [22]. In a similar vein, the literature reports that overconfident managers tend to disclose environmental issues voluntarily as an instrument of assurance to recover negative images resulting from unfavorable events [23]. In addition, this paper examines the moderating role of female executives and industry-level competition on the association between $\mathrm{CEO}$ overconfidence and corporate value. In the literature, female executives are more careful about the shareholders welfare and bring comprehensive eco-friendly solutions with creative perspectives, which results in flexible board decision making [24]. Moreover, prior studies report that female directors are less overconfident and more likely to pursue professional assistance than their male counterparts $[25,26]$. This monitoring mechanism can harmonize the negative side effects of overconfident managers and improve the quality of voluntary greenhouse gas (GHG) emissions. Similarly, industry-level competition uses an external governance mechanism that enforces managers to exercise their best efforts to not fall behind in the competition. Good governance mechanisms result in better monitoring by outside stakeholders, which also disciplines managers to work harder to satisfy the interest of outside shareholders. As a result, the quality of voluntary greenhouse gas (GHG) emissions could increase.

This study finds the following outcomes in a sample that consists of 13,334 firm-year observations listed in the Korean Stock market. First, overconfident managers are more likely to engage in voluntary greenhouse gas (GHG) emissions. These empirical findings imply that overconfident managers strategically exhibit their environmental awareness by conducting voluntary disclosure of greenhouse gas (GHG) emissions. These acts of voluntary disclosure can draw responsiveness and compliments from associated shareholders, which magnify their favorable self-image. Second, a positive relationship between managerial overconfidence and long-term firm value is strengthened with female representation on board. Given the fact that board diversity is a moderator that improves managerial effectiveness in an organization, overconfident managers who engage in voluntary environmental 
disclosure can take advantage of corporate value improvement [27]. Finally, this study offers evidence that a positive association between voluntary disclosure of greenhouse gas (GHG) emissions by overconfident CEOs and firm value intensifies with an increased degree of industry-level competition. These outcomes indicate that high product market competition is a market force to mitigate overconfident managerial opportunism, thereby improving the disclosure environment and firm value [28-30]. All the aforementioned results remain robust with the procedure through a firm fixed effect model to alleviate the endogeneity concerns. As a result of analyzing the impact of the corporate life cycle, it was found that companies entering the maturity stage more voluntarily disclose their greenhouse gas (GHG) emissions than those in the growth period.

The rest of this study proceeds as follows. Section 2 offers the prior research and develops the hypotheses. In Section 3, the study explains the research design and data. Section 4 presents the empirical analyses' results of the study, and Section 5 summarizes and concludes the study.

\section{Prior Research and Hypothesis Development}

\subsection{CEO Overconfidence and Voluntary Disclosure of Greenhouse Gas Emissions}

The interest in the risk of climate change from professional investors and various market participants has grown by about 18 times over the last decade. Some financial analysts reflect information on greenhouse gas (GHG) emissions in their corporate valuations and investment recommendations [31]. Some scholars anticipate that concerns regarding the relationship between greenhouse gas (GHG) emissions and global climate change could play a role in inducing the redistribution of valuation from companies that cannot successfully control greenhouse gas (GHG) emissions to companies that effectively manage and distribute resources. Despite this concern, research into why some companies voluntarily disclose greenhouse gas (GHG) emissions is rare.

Generally, firms that disclose specific information can reduce information asymmetry between managers and shareholders, thereby enabling the efficient allocation of limited resources [13]. The voluntary disclosure of greenhouse gas (GHG) emissions by managers indicates that it provides transparent non-financial information to the relevant investors to warn them of the future potential liability that could be imposed upon the company due to greenhouse gas emissions. If a firm does not disclose information on greenhouse gas (GHG) emissions, then stakeholders will not only charge the corporate greenhouse gas (GHG) emissions, but also regard the act of non-disclosure as a negative signal and discipline non-disclosing companies [32]. Furthermore, if shareholders bear the cost for information of non-disclosure greenhouse gas (GHG) emissions in the short-term, these increased costs will ultimately pass on to the corporate financing costs [33]. Regarding this, prior studies on firms that voluntarily disclose their corporate social responsibility (CSR) report lead to a reduction in the cost of equity capital [5].

Voluntary disclosure can be strategically used to alleviate adverse events, such as product recalls, employee strikes, and environmental issues, by providing a good information environment to the stakeholders [5]. It is also helpful in terms of a decrease in potential regulatory involvement [8]. For example, even when chemical firms recognized negative stock returns after a substantial chemical leak, the stock price rapidly recovers for firms with a high level of environmental disclosure. Moreover, chemical firms with better environmental disclosures report a weak adverse reaction to environmental regulations than other firms [8,9]. A corporate reputation for environmental responsibility is formed by social environmental responsibility, product quality, ownership structure, media visibility, financial performance, and board composition. Thus, voluntary greenhouse gas (GHG) emission disclosure, even without activity modifications, can show that firms are paying attention to the external environment and signal dedication to being good to others. Overall, these findings support the notion that managers can employ the disclosure of greenhouse gas (GHG) emissions as a strategic tool to address their responsiveness to social and regulatory issues. 
CEO overconfidence is a psychological characteristic that impacts corporate environmental policy [34,35]. Prior studies report that overconfident managements overestimate their capacity to predict future operating cash flows through productive investment opportunities. Generally, people with narcissistic characters have a strong need for responsiveness and admiration. In this sense, for narcissistic CEOs, voluntary disclosure of greenhouse gas (GHG) emissions could provide significant opportunities to collect attention. Petrenko et al. (2016) document three reasons to link narcissistic management to environmental disclosures [16]. First, voluntary disclosure of greenhouse gas (GHG) emissions is a value-relevant policy that appears friendly to environmental issues. Second, disclosures of greenhouse gas (GHG) emissions are related to environmentally sensitive audiences, media focus, and praise. Third, firms with high levels of environmental disclosures can mask and control their current status by bringing stability and diversity to the opportunities that overconfident managers seek from their attentive and responsive shareholders. Petrenko et al. (2016) support a positive relationship between CEO overconfidence and environmental disclosure activities [16]. Moreover, firms with a high level of environmental disclosure can reduce uncertainty from potential environmental liability and mitigate financial and litigation risk [36,37]. Collectively, the extent that stakeholders evaluate firms with high levels of disclosure on greenhouse gas (GHG) emissions as being more environmentally responsible, means that overconfident CEOs have incentives to voluntarily disclose environmental issues. From this reasoning, this study proposes the following hypothesis:

Hypothesis 1. CEO overconfidence is positively associated with voluntary disclosure of greenhouse gas (GHG) emissions.

\subsection{The Internal Governance Mechanism-The Effect of Female Executives}

Based on Jensen and Meckling's agency theory, there is a possibility that overconfident managements are likely to maximize their private benefits through opportunistic behavior due to misaligned interests with shareholders [22]. Overconfident managers may manage internal free cash flows by adopting investments with negative net present values (NPVs), and this is because they are likely to overvalue their investing returns [38]. Furthermore, Malmendier and Tate [17] show that overconfident managements sometimes overpay for M\&A trade when they are involved in value-destroying mergers [39]. Based on the free cash flow hypothesis, these opportunities are derived from their empire-building tendency and overestimation of their ability to manage merged companies. As there is profound information asymmetry between insiders and outsiders, these phenomena of personal bias when taking advantage of the shareholders' benefit would intensify. Collectively, all of these studies stress the significance of monitoring and controlling mechanisms to discourage overconfident management from sub-optimal investment choices.

Even though greenhouse gas (GHG) emissions information would be helpful to shareholders to recognize future liability, this information is self-reported, voluntary and unassured. Thus, these disclosures could be considered reliable through the effective monitoring of corporate governance. In these circumstances, a female board of directors can affect environmental managerial decision-making, since directors of different genders and cultural backgrounds raise questions that may not have been asked questioned by a board of directors with more traditional backgrounds [40,41]. In recent years, a broadly recognized feature of board diversity in a business boosts managerial effectiveness on corporate financial consequences and is a key mechanism for corporate governance [42]. For example, firms with higher female representation in board meetings are likely to report higher stock returns and market assessment [43]. However, the literature states that this positive relationship is maintained only for firms with more deficient corporate governance mechanisms [40]. Moreover, there is a study reporting a non-linear association between the number of female executives and economic consequences. Specifically, if only a small number of female executives are included in the board meetings, there is no relationship 
with financial performance. However, if three or more female boards are involved in a board meeting, the financial benefits intensify [43]. In sum, more female representation on a board is associated with more share buybacks [44], more innovation [45], less managerial opportunism, and less empire-building through M\&A acquisitions [25].

Female executives on boards have been observed in the overconfidence literature, and they are less likely to show overconfidence compared to their male coworkers [41]. Regarding investment policy, female directors are less likely to engage in M\&A deals, debt issuances [41], and overvaluation on acquisition profits [25]. Further, female executives are widely recognized as more socially responsible. For example, prior research provides evidence that female representation is positively related to CSR ratings and being recorded as CSR initiatives in the Kinder Lydenberg Domini (KLD) ratings [46]. This is in line with Post et al. (2011), who report that women directors are associated with a higher quantity and quality of CSR disclosure and the highest scores in the environmental section [47]. For this reason, I argue that firms with frequent female representation on boards decrease the risk of CEO overconfidence and boost the voluntary disclosure of greenhouse gas (GHG) emissions. Given the fact that voluntary disclosure is an effective way of increasing firm value and disclosing greenhouse gas (GHG) emission is conducted by the managers' discretion, this study proposes the following hypothesis:

Hypothesis 2-1. Female executives will moderate the relationship between CEO overconfidence and firm value.

\subsection{The External Governance Mechanism-The Effect of Industry-Level Competition}

The existing literature on the link between industry-level competition, CEO overconfidence, and corporate disclosure environments are inconsistent [48]. On the one hand, industry-level competition is an effective governance mechanism to mitigate agency costs [49-51]. Generally, competition plays a disciplinary mechanism to limit managers' opportunistic behaviors related to earning disclosure, which leads to an improvement in the quality of the disclosure environment [52]. According to Dhaliwal et al. (2012), higher industry-level competition is related to more timely recognition of losses in income statements [53]. Darrough and Stoughton (1990) find that a higher competitive market, which potential competitors can enter with lower market entry costs, encourages better disclosure of negative corporate information by discouraging the further entry of competitors to the present market [54]. Laksmana and Yang (2012) report that earning management is less prevalent among firms in more competitive markets [52]. Li et al. (2013) demonstrate a positive association between the level of competition and voluntary disclosure of industry-level managerial guidance [55], and Cheng et al. (2013) show that product market competition is positively related to several earnings attributes [56]. Further, Stivers (2004) provides evidence that the disclosure of proprietary information can reinforce market competition because this decreases information asymmetry costs, thereby creating more favorable financing conditions [57]. The industry-level competition also limits managerial expropriation of shareholders' wealth; therefore, firms in industry-level, highly competitive markets are likely to have transparent disclosure environments.

On the other hand, some prior studies raise an opposing view that product market competition can decrease the quality of disclosure environments. If there is enough product market competition, firms can precisely evaluate managerial performance compared to their competitors [58,59], and this also strengthens managements' career concerns [60]. In line with this, DeFond and Park (1999) demonstrate that firms with a high degree of industry-level competition are positively associated with frequent CEO turnover compared to firms in less competitive industries [61]. Accordingly, it is natural that managements in highly competitive markets tend to withhold negative information, which leads to a less informative disclosure environment. In these competitive markets, management strategies and corporate gains are strongly influenced by the behavior of competitors. Furthermore, the relationship between industry-level competition and the disclosure environment may 
be linked to industrial innovation strategy. As innovative firms such as biotech are related to information complexity, their R\&D expenditure is difficult to estimate. Therefore, it is challenging to properly assess and predict corporate value in competitive industries because overconfident managers may be hesitant to disclose greenhouse gas (GHG) emission information.

The mixed results of prior studies regarding the degree of greenhouse gas (GHG) emissions information disclosure in competitive product markets raise the following intriguing hypothesis. For clear understanding, all of the hypotheses are described in Figure 1.

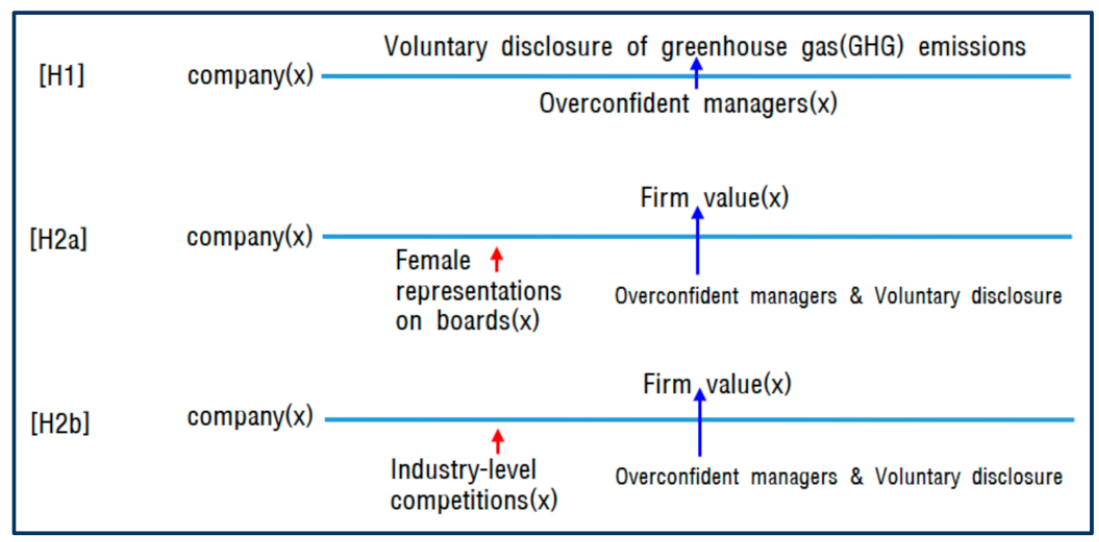

Figure 1. The hypothesis description.

Hypothesis 2-2. The industry-level competition will moderate or intensify the relationship between CEO overconfidence and firm value.

\section{Research Design}

\subsection{Estimation of CEO Overconfidence}

For measurement of CEO overconfidence, this study uses the model in McNichols and Stubben's (2008) research, which adjusts Tobin's $Q$ and controlling variables for asset growth, past investment expenditure, and the difference within the correlation between Tobin's Q and investment [62]. The research model consists of asset growth at the beginning of the year, past investment expenditure to manage a firm-specific aspect of the investment decision, and a change factor to the equation, since the CEO overconfidence is calculated from the residuals, measured by additional parts of the existing portion of the preceding investment. Finally, to consider variations within corporations in a similar industry-year, McNichols and Stubben (2008) expand the traditional Tobin's Q model by incorporating additional coefficients of quartiles for Tobin's Q [62]

$$
\begin{gathered}
I N V_{t}=\alpha_{0}+\beta_{1} Q_{t-1}+\beta_{2} Q_{-} Q R T 2_{t-1}+\beta_{3} Q_{-} Q R T 3_{t-1}+\beta_{4} Q_{-} Q R T 4_{t-1} \\
+\beta_{5} C F O_{t}+\beta_{6} \text { GROWTH H }_{t}+\beta_{7} I N V_{1}+\varepsilon_{t}
\end{gathered}
$$

INV = Capital expenditure; Q_QRT2 (Q_QRT3, Q_QRT4) = Q X an indicator variable for partitioning Tobin's $Q$ into quartiles ( 1 if $Q$ belongs to the second (third, fourth) quartile of its industry-year distribution and 0 otherwise); $\mathrm{CFO}=$ cash flows from operations/total assets; GROWTH = ln (total assets/total assets at the beginning of the year).

In this paper, $\mathrm{CEO}$ overconfidence is measured by residuals obtained from an estimation of Equation (1). OVERC (CEO overconfidence) is a dummy variable, equal to 1 if residuals are greater than zero, and 0 otherwise. 


\subsection{Research Model}

Hypothesis 1 predicts whether CEO overconfidence affects management's voluntary disclosure of greenhouse gas (GHG) emissions. To test the first hypothesis, this study uses the following logistic regression model by employing Equation (2)

$$
\begin{gathered}
G H G_{t+1}=\alpha_{0}+\beta_{1} \text { OVERC } C_{t}+\beta_{2} \text { SIZE }_{t}+\beta_{3} L E V_{t}+\beta_{4} \text { QUICK }_{t}+\beta_{5} T A_{t}+\beta_{6} M T B_{t}+\beta_{7} R O A_{1} \\
+\beta_{8} T A N G_{t}+\beta_{9} D A_{1}+\sum I N D+\sum Y R+\varepsilon_{t}
\end{gathered}
$$

GHG = a measure of voluntary disclosure of greenhouse (GHG) emissions, which is equal to 1 if firms disclose information on greenhouse gas (GHG) emissions, and 0 otherwise; OVERC $=$ a measure of CEO overconfidence, which is equal to 1 if residual from McNichols and Stubben (2008)'s research model is greater than zero, and 0 otherwise; SIZE $=\log$ (total assets); LEV = total liabilities / total assets; QUICK = (current assets-inventories) / (current liabilities); $\mathrm{TA}=$ (net income-cash flow from operation) / (total assets); MTB = market value of equity / book value of equity; ROA = net income / total assets; TANG = tangible assets / total assets; DA = discretionary accrual measured by model in Kothari et al. (2005).

In Equation (2), the dependent variable is GHG, and it measures whether managers voluntarily disclose information on greenhouse gas (GHG) emissions. This study obtains information on greenhouse (GHG) emissions from the Carbon Disclosure Project (CDP) data. The CDP is an independent non-profit institution that facilitates greenhouse gas (GHG) emission data collection. They ask for firms to provide information on greenhouse gas (GHG) emissions by responding to a questionnaire. For this reason, responding to the questionnaire indicates a voluntary disclosure decision from the management regarding greenhouse gas (GHG) emissions. This paper uses a lagged dependent variable to manage the endogeneity issues in the equation. Further, the test equation incorporates yearfixed and industry-fixed dummy variables to control variations within firms across the same industry-year sample. If CEO overconfidence is positively related to the voluntary disclosure of greenhouse gas (GHG) emissions, each coefficient is expected to show a significantly positive value.

Hypothesis 2-1 tests whether female representation on boards moderates the negative relationship between CEO overconfidence and firm value. To test hypothesis $2-1$, this study uses sub-sample analysis using the ordinary least squares (OLS) regression according to Equation (3). The sub-samples are divided into two parts based on the woman variable, and are measured by a dummy variable which is equal to 1 if the board of directors includes at least one woman director and 0 otherwise.

$$
\begin{gathered}
F V_{t+1}=\alpha_{0}+\beta_{1} O V E R C_{t}+\beta_{2} G H G_{t}+\beta_{3} O V E R C \times G H G_{t}+\beta_{4} S I Z E_{t}+\beta_{5} L E V_{t}+\beta_{6} Q_{U U I C K_{t}}+\beta_{7} T A_{t 1} \\
+\beta_{8} M T B_{t}+\beta_{9} R O A+\beta_{10} T A N G_{t}+\beta_{11} D A_{1}+\sum I N D+\sum Y R+\varepsilon_{t}
\end{gathered}
$$

$\mathrm{FV}=$ Tobin's $\mathrm{Q}$ as calculated by (market value of equity + total liability) / (beginning book value of equity).

The dependent variable in Equation (3) is a firm value, calculated by Tobin's Q. Consistent with Equation (2), this paper used a lagged variable to test the long-term influence of CEO overconfidence with GHG disclosure on corporate value. The variable of interest in Equation (3) is the interaction term of OVERC $\times$ GHG.

Hypothesis 2-2 forecasts that positive or negative relationship between CEO overconfidence, voluntary disclosure of greenhouse gas (GHG) emissions, and firm value decreased (strengthened) with industry-level competition level; I create this association to test whether product market competition plays a monitoring mechanism role. To test hypothesis 2-2, this paper adopts sub-sample analyses using Equation (3). This sub-sample is divided into two parts: one part with a high degree of industry-level competition and the other with a low degree of industry-level competition. Similar to hypothesis 2-1, if industrylevel competition is useful for supervising CEO overconfidence, the coefficients of each group will display a positive value with significance. This study uses a measure of the Herfindahl-Hirschman Index (HHI) as a proxy for industry-level competition. This vari- 
able is measured by the sum of the squares of the industry-level market shares of corporate sales at the end of the year.

$$
H H I_{k}=\sum_{i=1}^{n}\left(\frac{\text { Sales }_{i k}}{\sum_{i=1}^{n} \text { Sales }_{i k}}\right)^{2}
$$

Sales $_{\mathrm{ik}}$ is calculated as the market share of sales for firm $i$ in industry $k$, and $n$ counts the number of companies incorporated in industry $k$ at the end of the year.

The value of this variable declines as the number of competitors increases, and increases with the variations in market share of the firm within the industry. Namely, $\mathrm{HHI}$ is adversely influenced by industry-level competition. To interpret this conveniently, I set a dummy variable that takes a value of one for the situation where the value of $\mathrm{HHI}$ is smaller than the median and 0 otherwise.

All of the equations in the study incorporate appropriate controls that may impact CEO overconfidence and corporate value [63-66]. Consistent with the literature, the study incorporates firm size (SIZE), leverage (LEV), the ratio of current assets (QUICK), total accrual (TA), market-to-book ratio (MTB), return on assets (ROA), the ratio of tangible assets (TANG), and discretionary accrual (DA) calculated by Kothari et al. (2005) [67]. The estimation methods for discretionary accrual (DA) are described in Equation (5).

$$
\frac{T A_{t}}{A_{t 1}}=\alpha_{0}+\beta_{1} \frac{1}{A_{t 1}}+\beta_{2} \frac{\Delta S_{t} \Delta A R_{t}}{A_{t 1}}+\beta_{3} \frac{P P E_{t}}{A_{t 1}}+\beta_{3} R O A_{t}+\varepsilon_{t}
$$

$\mathrm{TA}=$ net income - cash flow from operations; $\mathrm{S}=$ sales revenue; $\mathrm{AR}=$ accounts receivables; $\mathrm{PPE}=$ plant , property, and equipment; $\mathrm{ROA}=$ net income/total assets; $\mathrm{A}=$ total assets.

Specifically, this study uses a cross-sectional model for discretionary accruals (DA) and forecasts the equation for all industries according to its two-digit industry code. The final sample includes firms with 15 or more firm-year data to guarantee enough samples for parameter estimation. The residuals estimated from Equation (4) are proxies to anticipate the DA variable. The definitions of the rest of the control variables are given below each table.

\subsection{Sample Selection Procedure}

Table 1 displays the sample-selecting procedure. Excluding non-financial institutions, firms listed in the Korea Stock Exchange (KSE) and Korea Securities Dealers Automated Quotation (KOSDAQ) as of 31 December 2019 are incorporated in the data. Then, the data related to missing observations to measure $\mathrm{CEO}$ overconfidence, firm value, and control variables are deleted. The ultimate sample consists of 13,334 firm-year observations that meet the following criteria: (1) firms without financial institution; (2) firms with financial information that is collected from the KIS-VALUE database developed by Korea Investors Service, located in Seoul, South Korea, (3) firms with greenhouse gas (GHG) emissions data that are gathered from the Carbon Disclosure Project (CDP) reports. The CDP reports are an essential reference to measure greenhouse gas (GHG) emissions information, incorporating various issues, such as corporate management and information on the emission inventory, accounting for greenhouse gas (GHG), and climate change information. All of the responses for the CDP report are acquired through voluntary questionnaires, and these responses are used to promote transparency and corporate commitment to fight climate change. The top and bottom one percent of all the variables are winsorized to alleviate the effects of outliers. The industry distribution is described following Table 1. 
Table 1. The data description.

\begin{tabular}{ccc}
\hline Industry & Number of Firms & \% \\
\hline Food/Tobacco & 450 & 3.37 \\
\hline Textiles/Bags/Shoes & 305 & 2.29 \\
\hline Paper/Wood/Pulp & 261 & 1.95 \\
\hline Chemicals/Plastics & 2081 & 15.61 \\
\hline Nonmetals & 256 & 1.92 \\
\hline $\begin{array}{c}\text { Primary metals/Metals } \\
\text { Working in Process }\end{array}$ & 898 & 6.73 \\
\hline Machinery/Computer/Biotech/Vehicle & 4487 & 33.65 \\
\hline Construction & 428 & 3.21 \\
\hline Wholesale/Retail & 1060 & 7.95 \\
\hline Service/Publication & 3108 & 23.32 \\
\hline Total & $\mathbf{1 3 , 3 3 4}$ & $\mathbf{1 0 0}$ \\
\hline
\end{tabular}

\section{Empirical Results}

\subsection{Descriptive Statistics and Correlation Analyses}

The descriptive statistics on the variables of interest used in the analyses are presented in Table 2. The mean value of CEO overconfidence (OVERC) is 0.790 , and the value ranges from 0 to 1 . The mean (median) of the dependent variable, GHG, which is measured as whether firms disclose information on greenhouse gas (GHG) emissions, is 0.083 (0.000). Another dependent variable is FV, which is measured by Tobin's Q and shows the mean of 1.052. Further, the mean of $W$ is 0.169 , which shows that about $16 \%$ of sample firms include female executives on their boards. Finally, the mean value of HHI presents 0.498 and its standard deviation is 0.500 .

Table 2. Descriptive statistics.

\begin{tabular}{cccccc}
\hline Variables & Mean & STD & Q1 & Median & Q3 \\
\hline OVERC & 0.790 & 0.407 & 1.000 & 1.000 & 1.000 \\
GHG & 0.083 & 0.276 & 0.000 & 0.000 & 0.000 \\
$F V$ & 1.052 & 1.078 & 0.413 & 0.700 & 1.268 \\
W & 0.169 & 0.385 & 0.000 & 0.000 & 0.000 \\
HHI & 0.498 & 0.500 & 0.000 & 0.000 & 1.000
\end{tabular}

Notes: OVERC $=$ a measure of CEO overconfidence which is equal to 1 if residual from research model in McNichols and Stubben (2008) is greater than zero, and 0 otherwise; GHG = a measure of voluntary disclosure of greenhouse gas (GHG) emissions which is equal to 1 if firms disclose information on greenhouse gas (GHG) emissions, and 0 otherwise; FV = Tobin's $\mathrm{Q}$ as measured by (market value of equity + total liability) / beginning book value of equity; $\mathrm{W}=$ a dummy variable which is equal to 1 if board of directors include at least one or more female director, and 0 otherwise; $\mathrm{HHI}=$ a dummy variable which is equal to $1 \mathrm{if} \mathrm{HHI}$ is smaller than the median, and 0 otherwise.

Table 3 delivers a correlation matrix of the main variables in the analysis. The correlations between the OVERC and the GHG are significantly positive. The correlations between the OVERC and the $\mathrm{W}$ are significant and negative. Besides, the correlations between the OVERC and the HHI are significantly negative. As expected, negative correlations between OVERC and FV were presented, with 1\% significance. Collectively, none of the relationships among variables are sufficient to raise the problem, and the test results of variance inflation factors (VIF), regarding the regression models, do not show multicollinearity concerns. 
Table 3. A correlation matrix.

\begin{tabular}{cccccc}
\hline & $\mathbf{( 1 )}$ & $\mathbf{( 2 )}$ & $\mathbf{( 3 )}$ & $\mathbf{( 4 )}$ & $\mathbf{( 5 )}$ \\
\hline \multirow{2}{*}{ OVERC (1) } & 1.000 & 0.045 & -0.026 & -0.038 & -0.030 \\
& & $(<0.0001)$ & 0.002 & $(<0.0001)$ & 0.001 \\
GHG (2) & & 1.000 & 0.010 & 0.040 & -0.126 \\
& & 0.210 & $(<0.0001)$ & $(<0.0001)$ \\
W (3) & & 1.000 & 0.121 & 0.176 \\
& & & $(<0.0001)$ & $(<0.0001)$ \\
HHI (4) & & & & 0.180 \\
& & & & & 0.000 \\
FV (5) & & & & & \\
& & & & & \\
\hline
\end{tabular}

(1) See Table 2 for definitions of the variables.

\subsection{Main Findings}

Table 4 shows the results of the multivariate tests of hypothesis 1 based on the dependent variable of greenhouse gas (GHG) emissions. The coefficient of the OVERC is positive and significant at the $1 \%$ level, after controlling for the various determinants of the voluntary disclosure of greenhouse gas (GHG) emissions. These significant and positive significant coefficients suggest that CEO overconfidence affects the managerial voluntary disclosure tendency of greenhouse gas (GHG) emissions, on average. In addition, these results support previous studies that document voluntary environmental disclosure being conducted as a tool to defend managements' decision making according to their private interests and opportunism. The disclosure of environmental information is sensitive to audiences in terms of respect, media attention, and compliment, all of which are powerful sources of attention for overconfident managers [15]. Consistent with the upper echelons view, corporate managers can affect strategic disclosure decisions and, therefore, firms tendency to disclose their environmental information may be influenced by managerial preferences and priorities, motivated by their personal features [16]. Control variables display significant coefficients, indicating that the research model is well-specified and alleviates the omitted variable issues. For example, SIZE, LEV, TA, ROA, and TANG are positively related to GHG, while QUICK, MTB, and DA are negatively associated with GHG. Similarly, most control variables in the research model are significant at the $10 \%$ level or higher. Overall, as supported by hypothesis 1, overconfident managers are likely to strategically disclose greenhouse gas (GHG) emission information that brings attention from outside investors.

Next, Table 5 reports the results of the multivariate analysis testing hypothesis 2-1 using Equation (3). Hypothesis 2-1 tests whether female directors within boards take the monitoring mechanism role to moderate the negative association between overconfident CEO, voluntary disclosure of greenhouse gas (GHG) emissions, and firm value. The coefficients of the interaction term between OVERC and GHG are positively and statistically significant in the first column of 'Effect of Female Executives'. This means that the negative relationship between CEO overconfidence and firm value moderates the strong monitoring power of female executives within boards. These results indicate that independent boards with female monitoring can manage and reconcile CEO overconfidence and adequately supervise and monitor strategic disclosure decisions such as disclosing greenhouse gas (GHG) emissions, which lead to improving firm value. These findings also support the notion that the voluntary disclosure of greenhouse gas (GHG) emissions by overconfident managers, which are not properly monitored by independent and flexible board leadership, can only waste settling disclosing costs and ultimately decrease the firm value in the long run. Hypothesis 2-1 is more evidently supported by the second column results, which report that a negative association between $\mathrm{CEO}$ overconfidence and corporate value is more evident in firms with no female leadership on boards. Most of the control variables show significant coefficients. Specifically, MTB, ROA, and TANG are positively related to greenhouse gas (GHG) emissions, while LEV is negatively associated with GHG in the first 
column. Similarly, most of the control variables in the second column are significant at the $10 \%$ level or higher. Overall, as supported by hypothesis $2 a$, overconfident managers with a voluntary disclosure of greenhouse gas (GHG) emissions are likely to be properly monitored with female representation on boards as an internal governance mechanism.

Table 4. CEO overconfidence and voluntary disclosure on greenhouse gas emission.

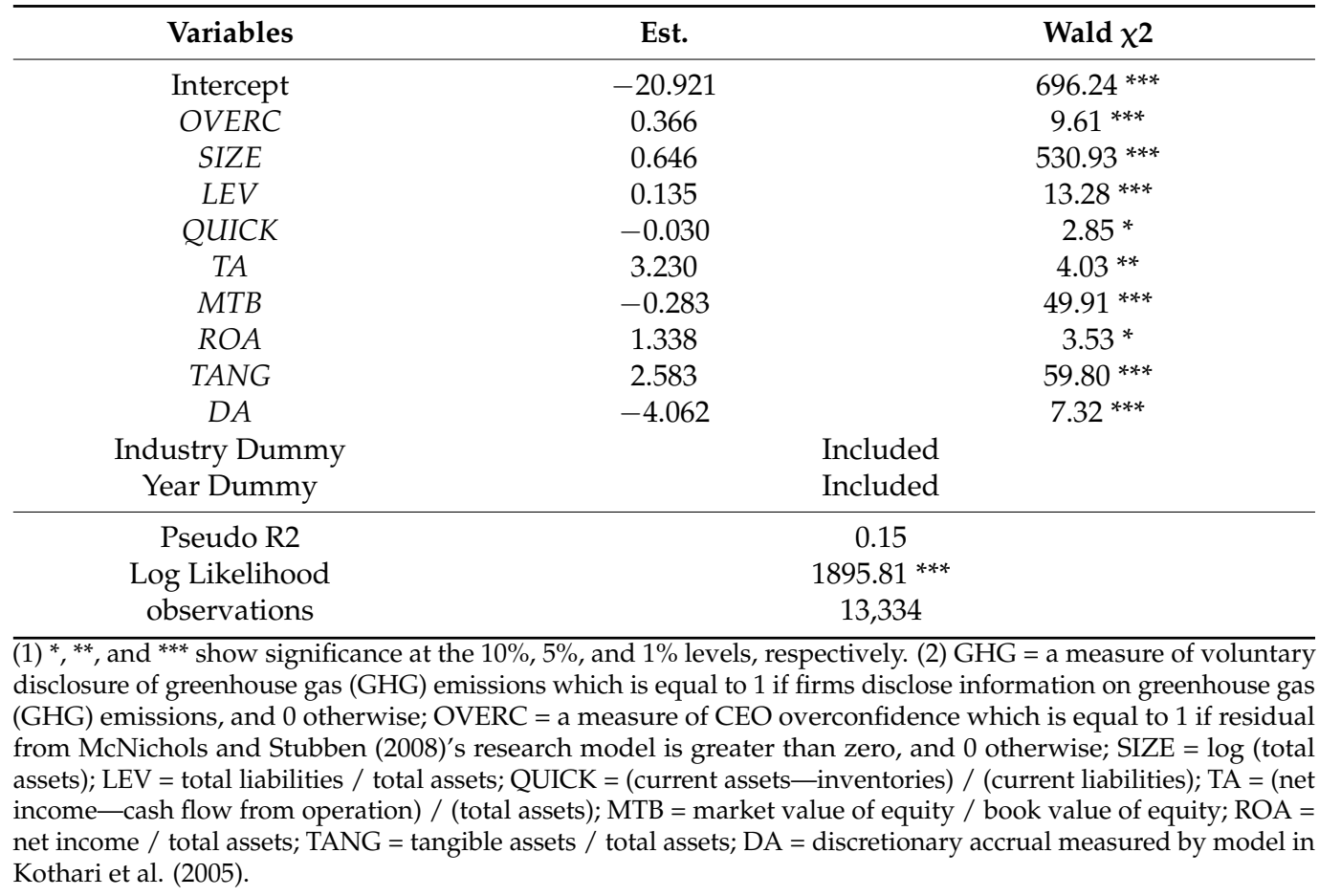

Table 5. The effect of female executives on the relationship between CEO overconfidence, voluntary disclosure on greenhouse gas emission, and firm value.

\begin{tabular}{|c|c|c|c|c|}
\hline \multirow{2}{*}{ Variables } & \multicolumn{2}{|c|}{ Effect of Female Executives } & \multicolumn{2}{|c|}{ Without Female Executives } \\
\hline & Coeff. & t-Stat. & Coeff. & t-Stat. \\
\hline Intercept & 0.325 & $2.04^{* *}$ & 0.353 & $3.96^{* * *}$ \\
\hline$O C^{1}$ & -0.013 & -1.10 & 0.004 & 0.80 \\
\hline GHG & 0.029 & 0.96 & -0.012 & -0.87 \\
\hline$O C X G H G$ & 0.087 & $2.09 * *$ & -0.050 & -1.13 \\
\hline SIZE & -0.002 & -0.48 & -0.002 & -0.64 \\
\hline$L E V$ & -0.338 & $-32.13^{* * *}$ & -0.285 & $-75.54^{* * *}$ \\
\hline QUICK & 0.029 & $15.57^{* * *}$ & 0.017 & $19.80^{* * *}$ \\
\hline $\mathrm{TA}$ & -0.108 & -0.47 & -0.636 & $-5.52^{* * *}$ \\
\hline MTB & 0.574 & $141.25^{* * *}$ & 0.542 & $225.11^{* * *}$ \\
\hline$R O A$ & 0.838 & $7.72 * * *$ & 0.453 & $9.62 * * *$ \\
\hline TANG & 0.321 & $4.02^{* * *}$ & 0.010 & 0.32 \\
\hline$D A$ & -0.106 & -0.52 & 0.433 & $4.10^{* * *}$ \\
\hline $\begin{array}{l}\text { Industry } \\
\text { Dummy }\end{array}$ & \multicolumn{2}{|c|}{ Included } & \multicolumn{2}{|c|}{ Included } \\
\hline Year Dummy & \multicolumn{2}{|c|}{ Included } & \multicolumn{2}{|c|}{ Included } \\
\hline Adj. $R^{2}$ & \multicolumn{2}{|c|}{0.92} & \multicolumn{2}{|c|}{0.87} \\
\hline F-value & \multicolumn{2}{|c|}{$1096.20^{* * *}$} & \multicolumn{2}{|c|}{$2486.83^{* * *}$} \\
\hline Observations & \multicolumn{2}{|c|}{2,264} & \multicolumn{2}{|c|}{11,070} \\
\hline
\end{tabular}

$(1)^{* *}$ and ${ }^{* * *}$ indicate significance at the $5 \%$ and $1 \%$ levels, respectively. (2) FV = Tobin's Q as measured by (market value of equity + total liability) / beginning book value of equity. (3) See Table 4 for definitions of other variables. 
Table 6 present the evidence for the multivariate tests of hypothesis 2-2 using subsample analyses. Hypothesis 2-2 examines whether industry-level competition plays a vital role in moderating the negative relationship between overconfident CEO and firm value as a powerful external governance mechanism. In the first column of Table 6, the coefficient of the interaction term between CEO overconfidence and GHG is positive and significant at the $5 \%$ level, after controlling for several determinants of firm value. Furthermore, in the second column of Table 6, the coefficient of the interaction term is not significant, even after controlling for proper control variables. Thus, this provides evidence that the negative association between overconfident CEO and firm value is attenuated with a higher degree of industry-level competition. These findings support the notion that product market competition plays an external governance mechanism in improving managerial disclosure environments to reconcile CEO overconfidence. In the presence of industry-level competition, managers' voluntary disclosures can increase transparency, enabling the tailoring of their product offerings. Prior studies find that more competitive industries are more likely to disclose firm-specific segment information than less competitive industries [68].

Table 6. The effect of industry-level competition on the relationship between CEO overconfidence, voluntary disclosure on greenhouse gas emission, and firm value.

\begin{tabular}{|c|c|c|c|c|}
\hline \multirow{2}{*}{ Variables } & \multicolumn{2}{|c|}{ High Industry-Level Competition } & \multicolumn{2}{|c|}{ Low Industry-Level Competition } \\
\hline & Coeff. & t-Stat. & Coeff. & t-Stat. \\
\hline Intercept & 0.429 & $3.52 * * *$ & 0.064 & $6.33 * * *$ \\
\hline$O C$ & -0.015 & $-2.07 * *$ & 0.001 & 0.85 \\
\hline GHG & 0.017 & 0.87 & -0.001 & -0.62 \\
\hline$O C X G H G$ & 0.074 & $2.31 * *$ & -0.018 & -1.61 \\
\hline SIZE & -0.006 & -1.39 & -0.001 & $-5.01^{* * *}$ \\
\hline LEV & -0.325 & $-49.08 * * *$ & 0.001 & 1.39 \\
\hline QUICK & 0.016 & $14.67^{* * *}$ & -0.000 & $-2.20 * *$ \\
\hline$T A$ & -0.251 & $-2.74 * * *$ & -0.030 & $-4.20 * * *$ \\
\hline MTB & 0.579 & $192.58^{* * *}$ & 0.987 & $3218.43^{* * *}$ \\
\hline$R O A$ & 0.550 & $7.81^{* * *}$ & 0.016 & $2.85^{* * *}$ \\
\hline TANG & 0.152 & $3.14^{* *}$ & -0.002 & -0.70 \\
\hline$D A$ & 0.053 & 1.05 & 0.026 & $4.96^{* * *}$ \\
\hline Industry Dummy & \multicolumn{2}{|c|}{ Included } & \multicolumn{2}{|c|}{ Included } \\
\hline Year Dummy & \multicolumn{2}{|c|}{ Included } & \multicolumn{2}{|c|}{ Included } \\
\hline Adj. $R^{2}$ & \multicolumn{2}{|c|}{0.91} & \multicolumn{2}{|c|}{0.92} \\
\hline F-value & \multicolumn{2}{|c|}{$2042.23^{* * *}$} & \multicolumn{2}{|c|}{$6059.14^{* * *}$} \\
\hline Observations & \multicolumn{2}{|c|}{6,649} & \multicolumn{2}{|c|}{6,685} \\
\hline
\end{tabular}

$(1)^{* *}$ and ${ }^{* * *}$ indicate significance at the 5\% and 1\% levels, respectively. (2) FV = Tobin's Q as measured by (market value of equity + total liability) / beginning book value of equity. (3) See Table 4 for definitions of other variables.

Similarly, Stivers (2004) finds a positive association between industry-level competition and the disclosure level of proprietary information [57]. They argue that, in competitive product markets with a large number of competitors, if at least one firm starts to reveal its private information, others are likely to also do so due to the competition. In other words, market contributors in competitive markets stimulate the disclosure of proprietary information, which leads to full disclosure, including environmental information. Consequently, the above evidence supports hypothesis 2-2 in that industry-level competition plays the role of an external monitoring mechanism to constrain CEO overconfidence and improve the disclosure environment for greenhouse gas (GHG) emissions.

\subsection{Robust Regressions}

As reported in the previous tables, CEO overconfidence affects the voluntary disclosure of greenhouse gas (GHG) emissions and firm value. It may cause endogeneity issues since the results are derived from different firm characteristics and not by managers' personal traits. A fixed-effect model is utilized to alleviate this concern. Through this process, unobserved heterogeneity within variables is controlled. By adjusting the group-level mean value, the aforementioned heterogeneity problem can be diminished from the data. 
Table 7 shows the empirical findings of the multivariate test of hypothesis $\mathrm{H} 1, \mathrm{H}$ 2-1, and H 2-2 by using a fixed-effect model. The coefficient of OVERC in Panel A is significantly positive, suggesting that overconfident CEOs are likely to voluntarily disclose information on greenhouse gas (GHG) emissions. Next, Panel B shows the empirical results of hypothesis 2-1, and the coefficient of the interaction term is positive, with $5 \%$ significance in the "Effect of Female Executives" sub-sample. This provides evidence that the negative relationship between CEO overconfidence and firm value is weakened by increasing female representation within boards. Finally, the coefficients of interaction term in Panel $\mathrm{C}$ show a significantly positive value, indicating that industry-level competition takes a robust external governance mechanism to moderate the adverse effects of CEO overconfidence. Collectively, all the empirical results remain robust after alternative testing to manage endogeneity issues.

Table 7. Robust regressions.

\begin{tabular}{|c|c|c|c|c|}
\hline \multicolumn{5}{|c|}{ Panel A. Hypothesis 1} \\
\hline Variables & \multicolumn{2}{|c|}{ Coeff. } & \multicolumn{2}{|c|}{ t-Stat. } \\
\hline Intercept & \multicolumn{2}{|c|}{-1.482} & \multicolumn{2}{|c|}{$-26.65^{* * *}$} \\
\hline OVERC & \multicolumn{2}{|c|}{0.018} & \multicolumn{2}{|c|}{$2.81 * * *$} \\
\hline Controls & \multicolumn{4}{|c|}{ Included } \\
\hline Adj. $R^{2}$ & \multicolumn{4}{|c|}{0.19} \\
\hline F-value & \multicolumn{4}{|c|}{$110.12^{* * *}$} \\
\hline Observations & \multicolumn{4}{|c|}{13,334} \\
\hline \multicolumn{5}{|c|}{ Panel B. Hypothesis 2-1 } \\
\hline \multirow{2}{*}{ Variables } & \multicolumn{2}{|c|}{ Effect of Female Executives } & \multicolumn{2}{|c|}{ Without Female Executives } \\
\hline & Coeff. & t-Stat. & Coeff. & t-Stat. \\
\hline Intercept & 0.325 & $2.04 * *$ & 0.352 & $3.96^{* * *}$ \\
\hline OVERC & -0.013 & -1.10 & 0.004 & 0.80 \\
\hline GHG & 0.029 & 0.96 & -0.012 & -0.87 \\
\hline OVERC X GHG & 0.087 & $2.09^{* *}$ & -0.050 & -1.13 \\
\hline Controls & \multicolumn{2}{|c|}{ Included } & \multicolumn{2}{|c|}{ Included } \\
\hline Adj. $R^{2}$ & \multicolumn{2}{|c|}{0.92} & \multicolumn{2}{|c|}{0.88} \\
\hline F-value & \multicolumn{2}{|c|}{$1096.20 * * *$} & \multicolumn{2}{|c|}{$2486.83 * * *$} \\
\hline Observations & \multicolumn{2}{|c|}{2,264} & \multicolumn{2}{|c|}{11,070} \\
\hline \multicolumn{5}{|c|}{ Panel C. Hypothesis 2-2 } \\
\hline \multirow{2}{*}{ Variables } & \multicolumn{2}{|c|}{ High Industry-Level Competition } & \multicolumn{2}{|c|}{ Low Industry-Level Competition } \\
\hline & Coeff. & t-Stat. & Coeff. & t-Stat. \\
\hline Intercept & 0.429 & $3.52 * * *$ & 0.064 & $6.33^{* * *}$ \\
\hline OVERC & -0.015 & $-2.07 * *$ & 0.001 & 0.85 \\
\hline GHG & 0.017 & 0.87 & -0.001 & -0.62 \\
\hline OVERC X GHG & 0.074 & $2.31^{* *}$ & -0.018 & -1.61 \\
\hline Controls & \multicolumn{2}{|c|}{ Included } & \multicolumn{2}{|c|}{ Included } \\
\hline Adj. $R^{2}$ & \multicolumn{2}{|c|}{0.91} & \multicolumn{2}{|c|}{0.92} \\
\hline F-value & \multicolumn{2}{|c|}{$2042.23^{* * *}$} & & \\
\hline Observations & & & & \\
\hline
\end{tabular}

\subsection{Growth Stage}

Corporate growth degree and development level vary depending on their lifecycles. However, there is a lack of research examining whether the corporate lifecycle influences strategic disclosure decisions regarding greenhouse gas (GHG) emissions. Thus, this paper attempts to conjecture the impact of the lifecycle on the relationship between CEO overconfidence and voluntary disclosure of greenhouse gas (GHG) emissions information. In this research, the corporate lifecycle is divided into two states: the growing and mature state. Firms in the mature state are capable of disclosing more or less information on greenhouse gas (GHG) emissions. On the one hand, as firms in the mature state have already compiled enough financial sources and an eco-friendly image, they might attempt 
to make fewer efforts in terms of voluntary disclosure behavior than firms in the growing state. On the other hand, there is a possibility that firms in the mature state regard the voluntary disclosure of environmental information as essential for raising financial capital through providing warnings about future environmental liability. Therefore, they have great incentives to actively disclose information on greenhouse gas (GHG) emissions.

The coefficient on OVERC in the first column in Table 8 displays a positive value with 1\% significance, whereas the coefficient on OVERC in the second column presents the insignificant value. These results indicate that overconfident managers in mature stage firms are more likely to affect the voluntary disclosure of information on greenhouse gas (GHG) emissions than firms in the growing stage.

Table 8. The effects of R\&D state.

\begin{tabular}{|c|c|c|c|c|}
\hline \multirow{2}{*}{ Variables } & \multicolumn{2}{|c|}{ Mature Stage } & \multicolumn{2}{|c|}{ Growing Stage } \\
\hline & Coeff. & t-Stat. & Coeff. & t-Stat. \\
\hline Intercept & -1.538 & $-18.77^{* * *}$ & -1.452 & $-18.84^{* * *}$ \\
\hline OVERC & 0.030 & $3.10 * * *$ & 0.007 & 0.85 \\
\hline SIZE & 0.060 & $19.16^{* * *}$ & 0.057 & $19.91 * * *$ \\
\hline$L E V$ & 0.010 & $2.37^{* *}$ & 0001 & 0.27 \\
\hline QUICK & -0.001 & -1.07 & 0.001 & 1.50 \\
\hline $\mathrm{TA}$ & -0.209 & $-1.89 *$ & -0.002 & -0.03 \\
\hline MTB & -0.008 & $-4.26 * * *$ & -0.004 & $-1.81 *$ \\
\hline$R O A$ & -0.038 & -0.82 & -0.082 & $-1.79 *$ \\
\hline TANG & 0.066 & $1.99^{* *}$ & 0.297 & $9.47 * * *$ \\
\hline$D A$ & 0.190 & $1.92 *$ & -0.005 & -0.05 \\
\hline Industry Dummy & \multicolumn{2}{|c|}{ Included } & \multicolumn{2}{|c|}{ Included } \\
\hline Year Dummy & \multicolumn{2}{|c|}{ Included } & \multicolumn{2}{|c|}{ Included } \\
\hline Adj. $\mathrm{R}^{2}$ & \multicolumn{2}{|c|}{0.24} & \multicolumn{2}{|c|}{0.13} \\
\hline F-value & \multicolumn{2}{|c|}{$82.36^{* * *}$} & \multicolumn{2}{|c|}{$42.31^{* * *}$} \\
\hline Observations & \multicolumn{2}{|c|}{6532} & \multicolumn{2}{|c|}{6802} \\
\hline
\end{tabular}

$(1)^{*}, * *$, and ${ }^{* * *}$ indicate significance at the $10 \%, 5 \%$, and $1 \%$ levels, respectively. (2) See Table 4 for definitions of other variables.

\section{Conclusions}

In recent decades, the world economy has developed rapidly. A number of companies have explored and documented the drivers, awareness, and economic consequences of environmental problems such as greenhouse gas (GHG) emissions, water pollution, and waste management [69-72]. In detail, fewer than 20 companies disclosed environmental information in the early 1990s, while more than 9000 companies reported sustainability or integrated reports by 2016, demonstrating investors' interest in environmental investments. The focus of previous studies on why companies disclose environmental information is mostly concentrated on external drivers [16]. According to these streams of research, external drivers to disclose environmental information include shareholder pressure [69, 70], institutional investors' force [71], and legal disclosure obligations [72]. In fact, the incentives to disclose environmental information can generally be explained by these external factors; however, if we focus only on these factors, it is hard to draw a complete picture of the corporate incentives to disclose environmental information. Therefore, this study suggests that, while filling the gaps in previous studies, more emphasis should be placed on how the CEO, the key decision-maker of a company, impacts the disclosure of environmental information. This is because the CEO significantly influences the decisionmaking regarding voluntary disclosure. Moreover, this paper attempts to show a creative and innovative way of influencing the psychological characteristics of CEO on strategic disclosure policy, leading them in an affirmative direction.

Using greenhouse gas (GHG) emissions data for 2011 to 2019, which listed firms with voluntary disclosure, this study finds that overconfident CEOs are aware of environmental issues and voluntarily disclose information on greenhouse gas (GHG) emissions. These results indicate that the voluntary disclosure of environmental information can be derived from an overconfident managements' private demand for attention and the formation of an eco-friendly self-image. As the disclosure of greenhouse gas (GHG) emissions offers 
a way of providing this, along with competitive advantages, overconfident managers may disclose environmental information voluntarily compared to less overconfident management. Next, this study reports that integration of the act of overconfident managers' voluntary disclosure into corporate valuation varies depending on the internal and external corporate governance. In detail, the positive association between the disclosure of greenhouse gas (GHG) emissions and firm value by overconfident managers is greater for firms with women executives on the boards and a high degree of industry-level competition. These results suggest that corporate internal and external governance are effective tools for monitoring and reconciling CEO overconfidence. Additionally, they are efficient at supervising managerial voluntary disclosure which may contribute to the improvement in corporate value. The main findings in the study are still consistent with the use of an alternative regression model of firm-fixed effects, and the results from additional analyses report that the relationship between CEO overconfidence, the voluntary disclosure of greenhouse gas (GHG) emissions, and firm value is more pronounced for firms in mature states.

The research outcomes in this study provide some innovative and meaningful contributions. First, by offering scholarly evidence on the corporate value effects of greenhouse gas (GHG) emissions disclosure, the study warns CEOs that may be helpful to make important decisions regarding the cost and benefit effects of resource allocation to measure and disclose environmental information. From a regulatory body perspective, the findings that managerial psychological features are incorporated in the voluntary disclosure decision may guide correction and enhancement in green policy, emphasizing the positive aspects of environmental disclosure. Likewise, greenhouse gas (GHG) emissions became the focus of global and international regulatory scrutiny, and voluntarily providing information on greenhouse gas (GHG) emissions indicates a corporate commitment to sustainability, given the finite supply of carbon fuels.

Second, the results contribute to the corporate governance literature, as board diversity and market competition can be a strong mechanism to monitor and control CEO overconfidence and lead to better sustainability disclosure. In other words, this paper supports female representation and product market competition as a means to diminish agency costs and help create an invisible contract among overconfident managers and stakeholders. There are very few studies on the disclosure of greenhouse gas (GHG) emissions in the Korean capital market, and existing studies report inconclusive, ambiguous, and contradictory empirical results. Therefore, this study has important implications by reporting the impact of managerial characteristics on greenhouse gas (GHG) emission information disclosure and corporate value.

Third, this study provides evidence on greenhouse gas (GHG) risk management in the context of equity value. In recent decades, there has been increasing discussion about the importance of greenhouse gas (GHG) risk management or carbon risk management. These studies argue that companies should adopt formal carbon risk managing systems, while climate change risk management is also one of the critical corporate strategies for sustainability and long-term success. Nevertheless, to date, investors have incorporated unassured and uncertain greenhouse gas (GHG) emissions information in their firm valuation because disclosure of this information is voluntary. This paper provides evidence of the degree to which the equity market employs environmental information for corporate assessment from sources other than regulatory bodies. These facts may stimulate regulators and accounting standard setters in their future policy deliberations concerning the disclosure of corporate carbon disclosure. Investors may require the following information to refine their valuation of voluntarily disclosing firms: (1) the volume of current greenhouse gas (GHG) emissions; (2) the relative efficiency of greenhouse gas (GHG) emissions compared to its industry peers; (3) information to prove corporate capacity to handle increased greenhouse gas (GHG) costs to customers.

Nevertheless, this paper suffers from several limitations which could be addressed in future research. First, the empirical analyses in this study are cross-sectional in na- 
ture. Thus, future studies on the long-term effect and pattern of voluntary disclosure of greenhouse gas (GHG) emission information in terms of firm value could help to resolve possible causality issues and strengthen the importance of the growing relationship between voluntary disclosure of greenhouse gas (GHG) emission information and firm value among Korean companies. Second, among the corporate governance in this paper, female representation needs careful interpretation. There are several factors that could impact the results, such as women being more overconfident themselves, and therefore not restricting the disclosure of information about greenhouse gas (GHG) emission, or companies that have more women on the board generally being more "open-minded", not only regarding gender issues, but in any other field. However, this study is meaningful as it is the first study to examine the effect of voluntary greenhouse gas (GHG) emission disclosures on investors' valuation in the Korean capital market, taking the characteristics of managers and governance structure into account.

Funding: This work was supported by Kyonggi University Research Grant 2020.

Institutional Review Board Statement: Not applicable.

Informed Consent Statement: Not applicable.

Data Availability Statement: Not applicable.

Conflicts of Interest: The author declares no conflict of interest.

\section{References}

1. Matsumura, E.; Prakash, R.; Vera-Munoz, S. Firm-value effects of carbon emissions and carbon disclosures. Acc. Rev. 2014, 89, 695-724. [CrossRef]

2. Griffin, P.; Sun, Y. Going green: Market reaction to CSR newswire releases. J. Acc. Public Policy 2012, 32, 93-113. [CrossRef]

3. Clarkson, P.; Fang, X.; Li, Y.; Richardson, G. The relevance of environmental disclosure: Are such disclosures incrementally informative? J. Acc. Public Policy 2013, 32, 410-431. [CrossRef]

4. Botosan, C.A.; Plumlee, M.A. A re-examination of disclosure level and the expected cost of equity capital. J. Account. Res. 2002, 40, 21-40. [CrossRef]

5. Dhaliwal, D.S.; Li, O.Z.; Tsang, A.; Yang, Y.G. Voluntary nonfinancial disclosure and the cost of equity capital: The initiation of corporate social responsibility reporting. Account. Rev. 2011, 86, 59-100. [CrossRef]

6. Guidry, R.P.; Patten, D.M. Market reactions to the first-time issuance of corporate sustainability reports: Evidence that quality matters. Sustain. Account. Manag. Policy J. 2010, 1, 33-50. [CrossRef]

7. Cho, C.H.; Freedman, M.; Patten, D.M. The role of environmental disclosures as tools of legitimacy: A research note. Account. Audit. Account. J. 2012, 25, 486-507. [CrossRef]

8. Blacconiere, W.G.; Patten, D. Environmental disclosures, regulatory costs and changes in share value. J. Acc. Econ. 1994, 18, 357-377. [CrossRef]

9. Blacconiere, W.G.; Northcutt, D. Environmental information and market reactions to environmental legislation. J. Account. Audit. Financ. 1997, 12, 149-178. [CrossRef]

10. Goss, A.; Roberts, G. The impact of corporate social responsibility on the cost of bank loans. J. Bank. Financ. 2011, 35, 1794-1810. [CrossRef]

11. Koh, P.-S.; Qian, C.; Wang, H. Firm litigation risk and the insurance value of corporate social performance. Strat. Manag. J. 2013, 35, 1464-1482. [CrossRef]

12. Minor, D.; Morgan, J. CSR as Reputation Insurance: Primum Non Nocere. Calif. Manag. Rev. 2011, 53, 40-59. [CrossRef]

13. Healy, P.M.; Palepu, K.G. Information asymmetry, corporate disclosure, and the capital markets: A review of the empirical disclosure literature. J. Account. Econ. 2001, 31, 405-440. [CrossRef]

14. Simon, M.; Houghton, S.M. The relationship between overconfidence and the introduction of risky products: Evidence from a field study. Acad. Manag. J. 2003, 46, 139-149.

15. Cyert, R.M.; March, J.G. A Behavioral Theory of the Firm; Prentice-Hall: Englewood Cliffs, NJ, USA, 1963.

16. Petrenko, O.V.; Aime, F.; Ridge, J.; Hill, A. Corporate social responsibility or CEO narcissism? CSR motivations and organizational performance. Strateg. Manag. J. 2016, 37, 262-279. [CrossRef]

17. Wallance, H.; Baumeister, R. The performance of narcissistic rises and falls with perceived opportunity for glory. J. Pers. Soc. Psychol. 2002, 82, 819-834. [CrossRef]

18. Blair, C.A.; Hoffman, B.J.; Helland, K.R. Narcissism in organizations: A multisource appraisal reflects different perspectives. Hum. Perform. 2008, 21, 254-276. [CrossRef]

19. Chatterjee, A.; Hambrick, D.C. It's all about me: Narcissistic chief executive officers and their effects on company strategy and performance. Adm. Sci. Q. 2007, 52, 351-386. [CrossRef] 
20. Rijsenbilt, A.; Commandeur, H. Narcissus enters the courtroom: CEO narcissism and fraud. J. Bus. Ethics 2013, 117, 413-429. [CrossRef]

21. Maccoby, M. Narcissistic leaders: The incredible pros, the inevitable cons. Harv. Bus. Rev. 2000, 78, 68-78.

22. Jensen, M.C.; Meckling, W.H. Theory of the firm: Managerial behavior, agency cost, and ownership structure. J. Financ. Econ. 1976, 3, 305-360. [CrossRef]

23. Godfrey, P.C.; Merrill, C.B.; Hansen, J.M. The relationship between corporate social responsibility and shareholder value: An empirical test of the risk management hypothesis. Strateg. Manag. J. 2009, 30, 425-445. [CrossRef]

24. Cumming, D.; Leung, T.Y.; Rui, O. Gender diversity and securities fraud. Acad. Manag. J. 2015, 58, 1572-1593. [CrossRef]

25. Levi, M.; Li, K.; Zhang, F. Director gender and mergers and acquisitions. J. Corp. Finan. 2014, 28, 185-200. [CrossRef]

26. Levi, M.; Li, K.; Zhang, F. Are women more likely to seek advice than men? Evidence from the boardroom. J. Risk Financ. Manag. 2015, 8, 127. [CrossRef]

27. Adams, R.B.; Ferreira, D. Women in the boardroom and their impact on governance and performance. J. Financ. Econ. 2009, 94, 291-309. [CrossRef]

28. Hart, O. The market mechanism as an incentive scheme. Bell J. Econ. 1983, 14, 366-382. [CrossRef]

29. Schmidt, K. Managerial incentives and product market competition. Rev. Econ. Stud. 1997, 64, 191-213. [CrossRef]

30. Baggs, J.; Bettignies, J. Product market competition and agency costs. J. Ind. Econ. 2007, 55, 289-323. [CrossRef]

31. Eccles, R.G.; Krzus, M.P.; Serafeim, G. Market interest in nonfinancial information. J. Appl. Corp. Financ. 2011, $23,113-127$. [CrossRef]

32. Milgrom, P.R. Good news and bad news: Representation theorems and applications. Bell J. Econ. 1981, 12, 380-391. [CrossRef]

33. Johnston, D.M.; Sefcik, S.E.; Soderstrom, N.S. The value relevance of greenhouse gas emissions allowances: An exploratory study in the related United States SO2 market. Eur. Account. Rev. 2008, 17, 747-764. [CrossRef]

34. Ahmed, A.S.; Duellman, S. Managerial overconfidence and accounting conservatism. J. Account. Res. 2013, 51, 1-30. [CrossRef]

35. Schrand, C.M.; Zechman, S.L. Executive overconfidence and the slippery slope to financial misreporting. J. Account. Econ. 2012, 53, 311-329. [CrossRef]

36. Choi, T.H.; Pae, J. Business ethics and financial reporting quality: Evidence from Korea. J. Bus. Ethics 2011, $103,403-427$. [CrossRef]

37. Deng, X.; Kang, J.K.; Low, B.S. Corporate social responsibility and stakeholder value maximization: Evidence from mergers. J. Financ. Econ. 2013, 110, 87-109. [CrossRef]

38. Malmendier, U.; Tate, G. CEO overconfidence and corporate investment. J. Financ. 2005, 60, 2661-2700. [CrossRef]

39. Malmendier, U.; Tate, G. Who makes acquisitions? CEO overconfidence and the market's reaction. J. Financ. Econ. 2008, 89, 20-43. [CrossRef]

40. Adams, R.B.; Funk, P. Beyond the glass ceiling: Does gender matter? Manag. Sci. 2012, 58, 219-235. [CrossRef]

41. Chen, G.; Crossland, C.; Huang, S. Female board representation and corporate acquisition intensity. Strateg. Manag. J. 2016, 37, 303-313. [CrossRef]

42. Campbell, K.; Mínguez-Vera, A. Gender diversity in the boardroom and firm financial performance. J. Bus. Ethics 2008, 83, 435-451. [CrossRef]

43. Joecks, J.; Pull, K.; Vetter, K. Gender diversity in the boardroom and firm performance: What exactly constitutes a "critical mass?". J. Bus. Ethics 2013, 118, 61-72. [CrossRef]

44. Evgeniou, T.; Vermaelen, T. Share buybacks and gender diversity. J. Corp. Finan. 2017, 45, 669-686. [CrossRef]

45. Torchia, M.; Calabrò, A.; Huse, M. Women directors on corporate boards: From tokenism to critical mass. J. Bus. Ethics 2011, 102, 299-317. [CrossRef]

46. Bear, S.; Rahman, N.; Post, C. The impact of board diversity and gender composition on corporate social responsibility and firm reputation. J. Bus. Ethics 2010, 97, 207-221. [CrossRef]

47. Post, C.; Rahman, N.; Rubow, E. Green governance: Board of director composition and environmental corporate social responsibility. Bus. Soc. 2011, 50, 189-223. [CrossRef]

48. Beyer, A.; Cohen, D.; Lys, T.; Walther, B. The financial reporting environment: Review of the recent literature. J. Account. Econ. 2010, 50, 296-343. [CrossRef]

49. Shin, J.Y.; Suh, C.W.; Park, J.I. The Effect of Corporate Governance on the Association between Earnings and Credit Ratings. Korean Manag. Rev. 2012, 41, 1309-1345.

50. Sohn, S.K.; Shin, I.H. A Study on the Effect of Product Market Competition on Analyst Forecast. Korean Manag. Rev. 2014, 43, 1029-1058.

51. Shin, I.H.; Lee, M.G.; Lee, E.C. Market Competition and Real Earnings Management-Focusing on Interaction with Corporate Governance. Korean Account. Rev. 2014, 39, 57-90.

52. Laksmana, I.; Yang, Y.W. Product Market Competition and Earnings Management: Evidence from Discretionary Accruals and Real Activity Manipulation; Working Paper; Kent State University and Wake Forest University: Winston Salem, NC, USA, 2012.

53. Dhaliwal, D.; Huang, S.; Khurana, I.; Pereira, R. Product Market Competition and Accounting Conservatism; Working Paper; University of Arizona: Canton, OH, USA; University of Arkansas: Fayetteville, AR, USA; University of Missouri: Columbia, MO, USA, 2012.

54. Darrough, M.N.; Stoughton, N.M. Financial disclosure policy in an entry game. J. Account. Econ. 1990, 12, 219-243. [CrossRef] 
55. Li, F.; Lundholm, R.; Minnis, M. A Measure of Competition Based on 10-K Filings. J. Account. Res. 2013, 51, 399-436. [CrossRef]

56. Cheng, P.; Man, P.; Yi, C. The impact of product market competition on earnings quality. Account. Financ. 2013, 53, 137-162. [CrossRef]

57. Stivers, A.E. Unraveling of information: Competition and uncertainty. BE J. Theor. Econ. 2004, 4, 1-30. [CrossRef]

58. Vickers, J. Concepts of Competition. Oxf. Econ. Pap. 1995, 47, 1-23. [CrossRef]

59. Meyer, M.; Vickers, J. Performance comparisons and dynamic incentives. J. Political Econ. 1997, 105, 547-581. [CrossRef]

60. Feriozzi, F. Paying for observable luck. RAND J. Econ. 2011, 42, 387-415. [CrossRef]

61. DeFond, M.; Park, C. The effect of competition on CEO turnover. J. Account. Econ. 1999, 27, 35-56. [CrossRef]

62. McNichols, M.; Stubben, S. Does earnings management affect firms' investment decisions? Account. Rev. 2008, 83, 1571-1603. [CrossRef]

63. Kalcheva, I.; Lins, K.V. International evidence on cash holdings and expected managerial agency problems. Rev. Financ. Stud. 2007, 20, 1087-1112. [CrossRef]

64. Laeven, L.; Levine, R. Complex ownership structures and corporate valuations. Rev. Financ. Stud. 2008, 21, 579-604. [CrossRef]

65. Padgett, R.C.; Galan, J.I. The effect of R\&D intensity on corporate social responsibility. J. Bus. Ethics 2010, 93, 407-418.

66. Servaes, H.; Tamayo, A. The impact of corporate social responsibility on firm value: The role of customer awareness. Manag. Sci. 2013, 59, 1045-1061. [CrossRef]

67. Kothari, S.P.; Leone, A.J.; Wasley, C.E. Performace matched discretionary accrual measures. J. Account. Econ. 2005, 39, $241-276$. [CrossRef]

68. Harris, M.S. The association between competition and managers' business segment reporting decisions. J. Account. Res. 1998, 36, 111-128. [CrossRef]

69. Bingham, J.B.; Dyer, W.G.; Smith, I.; Adams, G.L. A stakeholder identity orientation approach to corporate social performance in family firms. J. Bus. Ethics 2011, 99, 565-585. [CrossRef]

70. Surroca, J.; Tribó, J.A. Managerial entrenchment and corporate social performance. J. Bus. Financ. Account. 2008, 35, 748-789. [CrossRef]

71. Cox, P.; Brammer, S.; Millington, A. An empirical examination of institutional investor preferences for corporate social performance. J. Bus. Ethics 2004, 52, 27-43. [CrossRef]

72. Davies, S. The legal framework for corporate social responsibility. Gov. Dir. 2014, 66, 693-696. 